\title{
Uterine Corpus Carcinoma pT3b TNM
} Finding v7

National Cancer Institute

\section{Source}

National Cancer Institute. Uterine Corpus Carcinoma pT3b TNM Finding v7. NCI

Thesaurus. Code C89566.

Uterine corpus carcinoma that involves vagina or parametrial tissue. (from AJCC 7th Ed.) 